\title{
ECONOMICS OF Bt. COTTON IN WARDHA DISTRICT
}

\author{
A.P. Gandhre ${ }^{1 *}$, and U. T. Dangore ${ }^{2}$ \\ ${ }^{1}$ Post Graduate Student, Agricultural Economics \& Statistics Section, College of \\ Agriculture, Nagpur \\ ${ }^{2}$ Assistant Professor (Agril. Econ.) Agricultural Economics \& Statistics Section, College of \\ Agriculture, Nagpur \\ Corresponding author's email: akshay26gandhre@gmail.com
}

\begin{abstract}
:
Cotton is major cash crop in the country. For study three tahsils viz; Hinganghat, Wardha and Samudrapur were selected. Four villages were selected from each tahsil, from each village 10 farmers were selected and classify on the basis of farm size as small, medium and large farmers. The per hectare cost of production for overall 120 farmers at cost ' $\mathrm{A}_{1}$ ', 'A $\mathrm{A}_{2}$ ' was Rs.40794.10, cost ' $\mathrm{B}_{1}$ ' was Rs.42919.74, whereas cost 'B' $\mathrm{B}_{2}$ ' was Rs.63394.88 and cost ' $\mathrm{C}_{1}$ ' was Rs.45262.76, Cost ' $\mathrm{C}_{2}$ ' was Rs.65737.89 whereas cost ' $\mathrm{C}_{3}$ ' was Rs.72311.68. Overall level average gross return worked out to Rs.123001.10 with input-output ratio at cost ' $\mathrm{C}_{2}$ ' was 1:1.87. High cost of human labour was major problem which was expressed by 75 (62.50 per cent) farmers fallowed by lack of financial facility was expressed by 74 (61.67 per cent). Low level of productivity was 65 (54.16 per cent).
\end{abstract}

Key words: - cost, returns and production.

\section{INTRODUCTION:}

Cotton is a basic need of cloth, human being which is required right from his birth to death. It is the gift of nature providing fiber for clothing since time immemorial. It is one of the most important commercial cash crop besides serving as a source of natural fiber and oil and providing raw material to the textile and oil industry. It is outstanding economic venture. This contributes a major form of agricultural produce of growers which bringing then cash returns. It plays a vital role in Indian economy is concerned. It is one of the most important sources of foreign exchange, so it referred as "White Gold."

The Bt, is a short form of ubiquitous soil bacterium Bacillus thuringiensis. The Bt. Cotton refers to transgenic cotton which contains endotoxin protein including gene from soil bacterium Bacillus thuringiensis. Bt. was register as a pest control agent in 1961 under the Federal Insecticide and Rodenticide act in the U.S.A. In India Bt. formulation have been registered under Pesticide act 1968. The first transgenic plant was developed in 1983 in tobacco (Fraley et.al. 1983) in U.S.A. In cotton, the first transgenic plant eas developed in 1987 in U.S.A. by Monsanto, Delta and Pine companies. Bt. cotton, which confers resistance to important insect pest of cotton was first adopted in India as hybrids in 2002.

The government of India through Genetic Engineering Approval Committee (GEAC), Ministry of Environment and Forest considered the proposal for the commercial release of $\mathrm{Bt}$. cotton in its meeting held on 26 th March, 2002 after the careful and in-depth consideration, accorded approval for release Initially it was approved only for the Central Zone (Gujarat, Maharashtra and Madhya Pradesh) and Southern Zone (Tamil Nadu, Andhra Pradesh and Karnataka). The GEAC has approved the commercial cultivation of Bt. cotton in North Zone from the year 2005-06. During 2007-08 
the GEAC also approved the Boll Guard (BG II) of Bt. hybrids for its commercial cultivation.

The major cotton producing countries are India, China, United States, Pakistan, Brazil, Turkey. The production during 2014-15 was 6.4 million metric tonnes in India, 6.5 million metric tonnes in China, 3.6 million metric tonnes in United States, 2.3 million metric tonnes in Pakistan, 1.5 million metric tonnes in Brazil ,0.8 million metric tonnes in Turkey. Cotton is a major cash crop in the country. The area under cotton in India during 20152016 is 118.77 lakh ha with production 338.00 lakh bales. The average productivity of cotton crop in India is $484 \mathrm{~kg} / \mathrm{ha}$. The soil of Maharashtra which is called as black cotton soil most suitable for the cultivation of cotton. However the climate and soil in different part of Maharashtra are different. The area under cotton in Maharashtra during 2015-2016 is 38.27 lakh ha. with average productivity 333 $\mathrm{kg} / \mathrm{ha}$.

Vidarbha region is most suitable for cultivation of cotton. The area under cotton in Vidarbha during 2015-2016 is 14.76 lakh ha. Wardha, Amaravti, Akola, Yavatmal, Buldhana are called as cotton district of Vidarbha. Cotton is popularly known as "White Gold" in these districts. The area under Bt. cotton in Wardha district during 2015-2016 is 226474ha with average productivity $701.60 \mathrm{~kg} / \mathrm{ha}$ (SAO, Wardha). The adoption of Bt. cotton could help in protecting the crop against the potentially most damaging pest and thus could reduce the risk of crop failure. The Bt. cotton has more area under Wardha district hence in view of the importance of Bt. cultivation, the present study were undertaken to study the socioeconomic characteristics of selected cultivators, to analyse the cost and returns of Bt. cotton production and to identify the problems face by the farmers in production of Bt. cotton.

\section{MATERIAL \& METHODS:}

The present study was undertaken in Wardha district of Vidarbha region. In first stage district was selected purposively.. In the second stage of multi-stage sampling design three tahasil were selected on the basis of potential area under Bt. cotton cultivation. The Wardha district includes eight tahasils, out of eight tahasils the three tahasil i.e. Hinganghat, Samudrapur and Wardha were selected on the basis of highest area under Bt. cotton cultivation for the present study. In third stage, from each tahasils four villages were randomly selected. Total twelve villages were selected. From each village 10 farmers were selected randomly overall 120 Bt. cotton cultivators were selected for the present study. The data pertained for the year 2016-17.

The required data was collected by personal interview method by using pre-tested scheduled. The data pertained for the year 2016-17. The collected data then tabulated and simple tabular analysis was carried out and standard cost concept was used. Cost concepts includes Cost $\mathrm{A}_{1}, \mathrm{~A}_{2}, \mathrm{~B}_{1}, \mathrm{~B}_{2}, \mathrm{C}_{1}, \mathrm{C}_{2}$ and $\mathrm{C}_{3}$.

Cost $\mathrm{A}_{1}=$ All actual expenses in cash and kind incurred in production by the producer. The following items are included in cost $A_{1}$

1) Wages of hired human labour.

2) Wages of permanent labour.

3) Wages of contract labour.

4) Wages of hired bullock labour.

5) Imputed value of owned bullock labour.

6) Charges of hired Machinery.

7) Imputed value of owned machinery.

8) Market rate of manures and fertilizer.

9) Market rate of seed.

10) Imputed value of owned seed.

11) Imputed value of manure. 
12) Market value of pesticides, herbicides, hormones, etc.

13) Irrigation charges.

14) Land revenue, cesses and other tax.

15) Depreciation on farm machinery, implements, equipment Farm buildings, Irrigation structures, etc.

16) Interest on working capital.

17) Miscellaneous expenses.

Cost $A_{2}=$ Cost $A_{1}+$ Rent paid for leased in land

Cost $B_{1}=$ Cost $A_{1}+$ Interest on value of owned capital assets (excluding land)

Cost $\mathrm{B}_{2}=$ Cost $\mathrm{B}_{1}+$ Rental value of owned land less land revenue + Rent paid for leased in land.

Cost $\mathrm{C}_{1}=$ Cost $\mathrm{B}_{1}+$ Imputed value of family labour.

Cost $\mathrm{C}_{2}=$ Cost $\mathrm{B}_{2}+$ Imputed value of family labour.

Cost $\mathrm{C}_{3}=$ Cost $\mathrm{C}_{2}+10$ percent of Cost $\mathrm{C}_{2}$ on account of managerial functions performed by farmers.

In the present study, the rent paid for leased inland was zero, as none of sample farmers took land on lease basis. Hence cost $A_{1}$ and cost $A_{2}$ are similar and simply called $C$.as cost $A$ and only cost $\mathrm{C}_{2}$ was estimated and presented as cost of cultivation in the result.

1. Gross return per rupee of investment $=\frac{\text { Gross return }}{\text { Total cost }}$

2. Cost of production (quintal) $=\frac{\text { Total } \cos t(\mathrm{Rs} / \mathrm{Ha})}{\text { Yield }(\mathrm{Q} t / \mathrm{Ha})}$

3. Gross return per quintal $=\frac{\text { Gross return }(\mathrm{Rs} . \mathrm{Ha})}{\text { Yield }(\mathrm{Q} t / \mathrm{Ha})}$

RESULT \& DISCUSSION:

It is revealed that the Table 1 presents the distribution of farmers in the three categories i.e. small, medium and large according to their size holding. Out of the total 120 selected cultivators 55.83 per cent cultivators belonged to the small holding groups, 30.83 per cent medium land holding group and 13.34 per cent were large farmers. On the basis of average size of holding 120 Bt. cotton cultivators were categorized in to small, medium and large size of holding contributed 1.35 ha, 3.28 ha. and 9.21 ha. respectively. While average size of holding at overall level was 2.99 ha.

Table 2 revealed that, the average family size of selected farmers was 1 male, 2 female and 2 children at overall basis. Total family member under small medium and large group of selected farmers were found to 4,5 and 6 respectively. The highest family members were observed in large size group. During the peak season, the children could also help the farmers in farm activities like weeding, picking etc.

Educational pattern of selected Bt. cotton growers in Wardha district

The information regarding the education pattern of selected Bt. cotton growers is presented in Table 3.

The education profile of selected farmers presented in Table 3 revealed that, at overall level 14.17 per cent of farmers are illiterate and rest of them have educated, among them 9.17 per cent, 11.66 per cent, 23.33 per cent, 24.17 per cent, 17.50 per cent people have completed their primary school, middle school, high school, higher secondary, graduate and above level of education respectively. Highest illiterate (17.90 per cent) people were observed in small size of holding.

\section{Land utilization pattern of selected cultivators in Wardha district}

The land utilization pattern of selected Bt. Cotton cultivators is presented in Table 4.

It is observed from Table 4 that, on and overall the gross cropped area was found 3.18 hectare, while 99.22 per cent area under cultivable land, followed by 6.29 per cent area sown more than ones. The Cropping intensity 
found under small, medium and large group of farmers were 101.11 per cent, 105.50 per cent and 110.61 per cent respectively. At overall level the cropping intensity was 107.18 per cent.

\section{Cropping pattern of selected Bt. cotton cultivators}

The percentage area allocated to different crops with reference to gross cropped area by the selected Bt. cotton growers has been presented in Table 5 .

It is observed from table 5 that, in kharif season proportionate area under cotton was highest as 59.11 per cent, followed by Soybean 20.44 per cent, Tur 13.20 per cent, Jawar 0.94 per cent to the gross cropped area, While in rabi season, the proportionate area under gram was highest as 3.46 per cent. It is revealed that cotton was major crop in kharif season while gram was one of the major crops in rabi season in study area.At overall level area under Bt. cotton was 59.11 per cent to the gross cropped area. In small, medium and large size group area under Bt. cotton was highest.

\section{Per hectare cost of cultivation of Bt. cotton}

The per hectare cost of cultivation of Bt. cotton grown by the small farmers is presented in Table 6.

It is revealed from the Table 6 that, the per hectare cost of production at cost ' $\mathrm{A}_{1}$,' $\mathrm{A}_{2}$ ' is Rs.42390.89, cost ' $\mathrm{B}_{1}$ ' is Rs.44464.74, whereas cost ' $\mathrm{B}_{2}$ ' is Rs.63812.73 and cost ' $\mathrm{C}_{1}$ ' is Rs.47966.53, Cost ' $\mathrm{C}_{2}$ ' is Rs.67314.52 whereas cost ' $\mathrm{C}_{3}$ ' is Rs.74045.98 which indicate the 10 per cent as a managerial cost. The major share of cost of cultivation goes towards cost ' $\mathrm{A}_{1}$ 'and cost ' $\mathrm{A}_{2}$ ' (62.97 per cent). In cost ' $\mathrm{A}_{1}$ ' and cost ' $\mathrm{A}_{2}$ ' share of hired human labour was 18.51 per cent, fertilizer 10.20 per cent, plant protection 9.90 per cent, machine hours 7.00 per cent, seed 5.91 per cent, bullock labour
4.41 per cent, all the above inputs are cash inputs for which farmers required to pay immediately from his pocket. Cost ' $\mathrm{B}_{1}$ ' contributes to 66.06 per cent, Cost $\mathrm{B}_{2}$ contribute 94.80 per cent to the total cost i.e. cost ' $\mathrm{C}_{2}$ '. The share of family labour was 5.20 per cent. The per hectare yield obtained by small farmers was 21.59 quintal with gross return of Rs.116299.64. In case of small size group the per Quintal cost of production was Rs.3429.64.

The per hectare cost of cultivation of Bt. cotton grown by the medium group farmers is presented in Table 7 .

It is revealed from the Table 7 that, the per hectare cost of production at cost ' $\mathrm{A}_{1}$ ', ' $\mathrm{A}_{2}$ ' is Rs.37321.94, cost ' $\mathrm{B}_{1}$ ' is Rs.39555.89, whereas cost ' $\mathrm{B}_{2}$ ' is Rs.60505.17 and cost ' $\mathrm{C}_{1}$ ' is Rs.41599.81, Cost ' $\mathrm{C}_{2}$ ' is Rs.62549.10 whereas cost ' ${ }^{\prime} \mathrm{C}_{3}$ 'is Rs.68804.04. The major share of cost of cultivation goes towards cost ' $\mathrm{A}_{1}$ ' and cost $A_{2}$ (59.67 per cent). Share of hired human labour was 18.96 per cent, fertilizer 10.57 per cent, plant protection 8.00 per cent, machine hours 6.96 per cent, seed 6.48 per cent all the above inputs are cash inputs for which farmers required to pay immediately from his pocket. Cost ' $\mathrm{B}_{1}$ ' contributes to 63.24 per cent, Cost $\mathrm{B}_{2}$ contribute 96.73 per cent to the total cost i.e. cost ' $\mathrm{C}_{2}$ '. The share of family labour was 3.27 per cent. The per hectare yield obtained by medium farmers was 23.06 quintal with gross return of Rs.125833.25. In case of medium size group the per quintal cost of production was Rs.2984.21.

The per hectare cost of cultivation of Bt. cotton grown by the large group farmers is presented in Table 8.

It is revealed from the Table 8 that, the per hectare cost of production at cost ' $\mathrm{A}_{1}$ ', ' $\mathrm{A}_{2}$ ' is Rs.42791.31, cost ' $\mathrm{B}_{1}$ 'is Rs.44809.68, whereas cost ' $\mathrm{B}_{2}{ }^{\prime}$ is Rs.65828.63 and cost ' $\mathrm{C}_{1}$ ' is 
Rs.45952.33, Cost ' $\mathrm{C}_{2}$ ' is Rs.66971.28 whereas cost ' $\mathrm{C}_{3}$ ' is Rs.73668.41 The major share of cost of cultivation goes towards cost ' $\mathrm{A}_{1}$ ' and cost ' $\mathrm{A}_{2}$ ' (63.90 per cent). Share of hired human labour was 20.48 per cent, fertilizer 10.05 per cent, plant protection 8.25 per cent, machine hours 8.07 per cent, seed 5.87 per cent all the above inputs are cash inputs for which farmers required to pay immediately from his pocket. Cost ' $\mathrm{B}_{1}$ ' contributes to 66.91 per cent, Cost ' $\mathrm{B}_{2}$ ' contribute 98.29 per cent to the total cost i.e. cost ' $\mathrm{C}_{2}$ '. The share of family labour was 1.71 per cent. The per hectare yield obtained by large farmers was 24.04 quintal with gross return of Rs.126196.25 In case of large size group the per quintal cost of production was Rs.3064.54.

The per hectare cost of cultivation of Bt. cotton grown by the overall 120 farmers is presented in Table 9.

It is revealed from the Table 9 that, the per hectare cost of production at cost ' $\mathrm{A}_{1}$ ', ' $\mathrm{A}_{2}$ ' is Rs.40794.10, cost ' $\mathrm{B}_{1}$ ' is Rs.42919.74, whereas cost ' $\mathrm{B}_{2}$ ' is Rs.63394.88 and cost ' $\mathrm{C}_{1}$ ' is Rs.45262.76, Cost ' $\mathrm{C}_{2}$ ' is Rs.65737.89 whereas cost ' $\mathrm{C}_{3}$ 'is Rs.72311.68 The major share of cost of cultivation goes towards cost ' $A_{1}$ ' and cost ' $A_{2}$ ' (62.06 per cent). Share of hired human labour was 19.23 per cent, fertilizer 10.25 per cent, plant protection 8.79 per cent, machine hours 7.29 per cent, seed 6.07 per cent all the above inputs are cash inputs for which farmers required to pay immediately from his pocket. Cost ' $\mathrm{B}_{1}$ ' contributes to 65.29 per cent, Cost ' $\mathrm{B}_{2}$ ' contribute 96.44 per cent to the total cost i.e. cost ' $\mathrm{C}_{2}$ '. The share of family labour was 3.56 per cent. The per hectare yield obtained by farmers was 22.89 quintal with gross return of Rs.123001.07 In case of large size group the per quintal cost of production was Rs.3158.82.

\section{Per hectare cost and returns from Bt. cotton}

The per hectare cost and returns from Bt. cotton is presented in Table 10 .

The input output ratio which is an indicator of economic efficiency in crop production for the crop and other discussion indicated that Bt. cotton registered a good input output ratio $1: 1.87$ means this is a profitable crop. The results obtained are in close agreement with the finding of Narayanamoorthy and Kalamkar (2006) they concluded that profit per hectare are higher for Bt. Cotton. Singh et al. (2016) concluded that, in Hissar district the average gross income per acre on medium farm were Rs.36799.40 as compared to large farm (Rs.36263.00) and small farm (Rs.34380.57).

\section{Constrains in production of Bt. cotton}

The information regarding the important problems faced by the growers is presented in Table 11.

It is revealed from Table 11 that, High cost of human labour was major problem which was expressed by 75 (62.50 per cent) farmers fallowed by lack of financial facility was expressed by 74 (61.67 per cent). Low level of productivity 60 (50.00 per cent) etc.

\section{REFERENCES:}

Alam M.K., Aboki E., Gidado E.H., Buba D.D. (2013). Economic analysis of cotton production in selected local Government areas of Taraba state, Nigeria. J. Agri. Sci. 4(1): 27-31.

Chethana K.S. and Singh D. (2005).Economics of cotton production in Haryana. J. Cotton Res. Dev.19 (1): 115-119.

Dass D., Singh V, Khatkar R.K., Singh J., Singh B. and Singh P. (2014). Economic analysis of Bt. cotton production in Haryana. J. Cotton Res. Dev. 28 (1):167-169. 
Narayanamoorthy A., Kalamkar S.S. (2006). Is Bt. cotton cultivation economically viable for Indian farmers? An empirical analysis.Economic and Political weekly. 41(26): 2716-2724.

Shelke R.D., Bhogaonkar M.M. and Chavan R.V. (2016). Cost, returns and profitability of Btcotton production in Beed district.Internat.J. of Com.\& Bus. Manage.,9(1): 58-61.

Singh B., Suhag K.S., Dass D., Rajkumar, Sing G. (2016). An economic analysis of Bt. cotton production in Hisar and Sirsa districts of Haryana.Journal of Cotton Research and Development. 30 (2):302-309.
Singh G., Singh G., Singh P., Suhag K.S., Singh B. and Singh J. ( 2015). An economic analysis of Bt. cotton in Sirsa district of Haryana. J. cotton Res. Dev. 29(1):163166.

Singh P. and Grover D.K. (2014). An economic evolution of Bt. cotton cultivation in Panjab.J. cotton res. dev.28(1):170-174.

Vaidkar R.D., Wahile D.P., Bele V.R. (2010). Economic and production of Bt. cotton in Yawatmal district of Vidarbha region. New Agriculturist 21(1, 2): 7-12.

Table 1: Distribution of farmers according to size of holding

\begin{tabular}{|c|c|c|c|}
\hline $\begin{array}{c}\text { Sr. } \\
\text { No. }\end{array}$ & Size of holding & $\begin{array}{c}\text { Farmer selected } \\
\text { (Nos.) }\end{array}$ & $\begin{array}{c}\text { Average size of holding } \\
\text { (ha.) }\end{array}$ \\
\hline 1 & Small (up to 2.00 ha) & $\begin{array}{c}67 \\
(55.83)\end{array}$ & 3.35 \\
\hline 2 & Medium (2.01 to 4.00 ha) & 37 & 3.28 \\
\hline 3 & Large (4.01 ha and above & $(30.83)$ & 9.21 \\
\hline 4 & Total & 16 & 2.99 \\
\hline
\end{tabular}

Table 2: Average family size of selected farmers

\begin{tabular}{|c|c|c|c|c|c|}
\hline \multirow{2}{*}{$\begin{array}{c}\text { Sr. } \\
\text { No. }\end{array}$} & \multirow{2}{*}{ Particulars } & \multicolumn{4}{|c|}{ Size of family (Nos.) } \\
\cline { 3 - 6 } & & Small & Medium & Large & Overall \\
\hline \multirow{2}{*}{1} & Male & 1 & 2 & 2 & $(20.00)$ \\
\hline 2 & Female & $(25.00)$ & $(40.00)$ & $(33.33)$ & 2 \\
& & 1 & 1 & 2 & $(40.00)$ \\
\hline 3 & Children & $(25.00)$ & $(20.00)$ & $(33.33)$ & $(40.00)$ \\
\hline 4 & Total & $(50.00)$ & $(40.00)$ & $(33.34)$ & 5 \\
& & 4 & 5 & 6 & $(100.00)$ \\
\hline
\end{tabular}

(Figures in parenthesis indicate per cent to total) 
Table 3: Educational pattern of selected farmers

(Nos.)

\begin{tabular}{|c|c|c|c|c|c|}
\hline \multirow{2}{*}{$\begin{array}{l}\text { Sr. } \\
\text { No. }\end{array}$} & \multirow{2}{*}{ Particulars } & \multicolumn{4}{|c|}{ Size group } \\
\hline & & Small & Medium & Large & Overall \\
\hline 1 & Illiterate & $\begin{array}{c}12 \\
(17.90)\end{array}$ & $\begin{array}{c}5 \\
(13.50)\end{array}$ & $\begin{array}{c}0 \\
(0.00)\end{array}$ & $\begin{array}{c}17 \\
(14.17)\end{array}$ \\
\hline 2 & $\begin{array}{l}\text { Primary school } \\
\text { (1 to } 4)\end{array}$ & $\begin{array}{c}7 \\
(10.45)\end{array}$ & $\begin{array}{c}3 \\
(8.11)\end{array}$ & $\begin{array}{c}1 \\
(6.25)\end{array}$ & $\begin{array}{c}11 \\
(9.17)\end{array}$ \\
\hline 3 & $\begin{array}{l}\text { Middle school } \\
\text { (5 to } 7 \text { ) }\end{array}$ & $\begin{array}{c}7 \\
(10.45)\end{array}$ & $\begin{array}{c}6 \\
(16.22)\end{array}$ & $\begin{array}{c}1 \\
(6.25)\end{array}$ & $\begin{array}{c}14 \\
(11.66)\end{array}$ \\
\hline 4 & $\begin{array}{l}\text { High school } \\
\text { (8 to } 10)\end{array}$ & $\begin{array}{c}19 \\
(28.36)\end{array}$ & $\begin{array}{c}7 \\
(18.92)\end{array}$ & $\begin{array}{c}2 \\
(12.5)\end{array}$ & $\begin{array}{c}28 \\
(23.33)\end{array}$ \\
\hline 5 & $\begin{array}{l}\text { Higher secondary (11 to } \\
\text { 12) }\end{array}$ & $\begin{array}{c}14 \\
(20.90)\end{array}$ & $\begin{array}{c}10 \\
(27.03)\end{array}$ & $\begin{array}{c}5 \\
(31.25)\end{array}$ & $\begin{array}{c}29 \\
(24.17)\end{array}$ \\
\hline 6 & Graduate and above & $\begin{array}{c}8 \\
(11.94)\end{array}$ & $\begin{array}{c}6 \\
(16.22)\end{array}$ & $\begin{array}{c}7 \\
(43.75)\end{array}$ & $\begin{array}{c}21 \\
(17.50)\end{array}$ \\
\hline 7 & Total & $\begin{array}{c}67 \\
(100.00)\end{array}$ & $\begin{array}{c}37 \\
(100.00)\end{array}$ & $\begin{array}{c}16 \\
(100.00)\end{array}$ & $\begin{array}{c}120 \\
(100.00)\end{array}$ \\
\hline
\end{tabular}

(Figures in parenthesis indicate per cent to total)

Table 4: Land Utilization pattern of selected cultivators

(Area: ha.)

\begin{tabular}{|c|c|c|c|c|c|}
\hline \multirow{2}{*}{$\begin{array}{l}\text { Sr. } \\
\text { No. }\end{array}$} & \multirow{2}{*}{ Particulars } & \multicolumn{4}{|c|}{ Size group } \\
\hline & & Small & Medium & Large & Overall \\
\hline 1 & Total land holding & $\begin{array}{c}1.35 \\
(100.00)\end{array}$ & $\begin{array}{c}3.28 \\
(100.00)\end{array}$ & $\begin{array}{c}9.21 \\
(100.00)\end{array}$ & $\begin{array}{c}2.99 \\
(100.00)\end{array}$ \\
\hline 2 & Current fallow & $\begin{array}{c}0.00 \\
(0.22)\end{array}$ & $\begin{array}{c}0.01 \\
(0.33)\end{array}$ & $\begin{array}{c}0.16 \\
(1.77)\end{array}$ & $\begin{array}{c}0.02 \\
(0.89)\end{array}$ \\
\hline 3 & Net cultivated area & $\begin{array}{c}1.35 \\
(99.78)\end{array}$ & $\begin{array}{c}3.27 \\
(99.67)\end{array}$ & $\begin{array}{c}9.05 \\
(98.51)\end{array}$ & $\begin{array}{c}2.97 \\
(99.22)\end{array}$ \\
\hline 4 & Irrigated area & $\begin{array}{c}0.00 \\
(0.00)\end{array}$ & $\begin{array}{c}0.10 \\
(3.05)\end{array}$ & $\begin{array}{c}0.45 \\
(4.88)\end{array}$ & $\begin{array}{c}0.16 \\
(5.35)\end{array}$ \\
\hline 5 & Area sown more than ones & $\begin{array}{c}0.01 \\
(0.66)\end{array}$ & $\begin{array}{c}0.18 \\
(5.44)\end{array}$ & $\begin{array}{c}0.96 \\
(10.45)\end{array}$ & $\begin{array}{c}0.21 \\
(6.29)\end{array}$ \\
\hline 6 & Gross cropped area & 1.36 & 3.45 & 10.01 & 3.18 \\
\hline 7 & Cropping intensity (\%) & 101.11 & 105.50 & 110.61 & 107.18 \\
\hline
\end{tabular}


Table 5: Cropping pattern of selected cultivators

(Area: ha)

\begin{tabular}{|c|c|c|c|c|c|}
\hline \multirow{2}{*}{$\begin{array}{l}\text { Sr. } \\
\text { No. }\end{array}$} & \multirow{2}{*}{ Particulars } & \multicolumn{4}{|c|}{ Size group } \\
\hline & & Small & Medium & Large & Overall \\
\hline $\mathbf{A}$ & \multicolumn{5}{|c|}{ Kharif Crops } \\
\hline 1 & Soybean & $\begin{array}{c}0.06 \\
(4.41)\end{array}$ & $\begin{array}{c}0.54 \\
(15.65)\end{array}$ & $\begin{array}{c}3.35 \\
(33.13)\end{array}$ & $\begin{array}{c}0.65 \\
(20.44)\end{array}$ \\
\hline 2 & Cotton & $\begin{array}{c}1.23 \\
(90.44)\end{array}$ & $\begin{array}{c}2.21 \\
(64.05)\end{array}$ & $\begin{array}{c}3.84 \\
(37.98)\end{array}$ & $\begin{array}{c}1.88 \\
(59.11)\end{array}$ \\
\hline 3 & Tur & $\begin{array}{c}0.07 \\
(5.14)\end{array}$ & $\begin{array}{c}0.48 \\
(13.91)\end{array}$ & $\begin{array}{c}1.74 \\
(17.21)\end{array}$ & $\begin{array}{c}0.42 \\
(13.20)\end{array}$ \\
\hline 4 & Jowar & $\begin{array}{c}0.00 \\
(0.00)\end{array}$ & $\begin{array}{c}0.04 \\
(1.15)\end{array}$ & $\begin{array}{c}0.12 \\
(1.19)\end{array}$ & $\begin{array}{c}0.03 \\
(0.94)\end{array}$ \\
\hline 5 & Total of Kharif crop & $\begin{array}{c}1.35 \\
(99.26)\end{array}$ & $\begin{array}{c}3.27 \\
(94.78)\end{array}$ & $\begin{array}{c}9.05 \\
(89.51)\end{array}$ & $\begin{array}{c}2.97 \\
(93.40)\end{array}$ \\
\hline B & \multicolumn{5}{|c|}{ Rabi Crops } \\
\hline 1 & Gram & $\begin{array}{c}0.00 \\
(0.00)\end{array}$ & $\begin{array}{c}0.10 \\
(2.89)\end{array}$ & $\begin{array}{c}0.58 \\
(5.74)\end{array}$ & $\begin{array}{c}0.11 \\
(3.46)\end{array}$ \\
\hline 2 & Wheat & $\begin{array}{c}0.01 \\
(0.74)\end{array}$ & $\begin{array}{c}0.08 \\
(2.33)\end{array}$ & $\begin{array}{c}0.39 \\
(3.86)\end{array}$ & $\begin{array}{c}0.09 \\
(2.83)\end{array}$ \\
\hline 3 & Other & $\begin{array}{c}0.00 \\
(0.00)\end{array}$ & $\begin{array}{c}0.00 \\
(0.00)\end{array}$ & $\begin{array}{c}0.08 \\
(0.79)\end{array}$ & $\begin{array}{c}0.01 \\
(0.31)\end{array}$ \\
\hline 4 & Total of Rabi & $\begin{array}{c}0.01 \\
(0.74)\end{array}$ & $\begin{array}{c}0.18 \\
(5.22)\end{array}$ & $\begin{array}{c}0.96 \\
(9.49)\end{array}$ & $\begin{array}{c}0.21 \\
(6.60)\end{array}$ \\
\hline 5 & Gross cropped area & $\begin{array}{c}1.36 \\
(100.00)\end{array}$ & $\begin{array}{c}3.45 \\
(100.00)\end{array}$ & $\begin{array}{c}10.01 \\
(100.00)\end{array}$ & $\begin{array}{c}3.18 \\
(100.00)\end{array}$ \\
\hline
\end{tabular}

(Figures in parenthesis indicate per cent to gross cropped area)

Table 6: Per hectare cost of cultivation (Small)

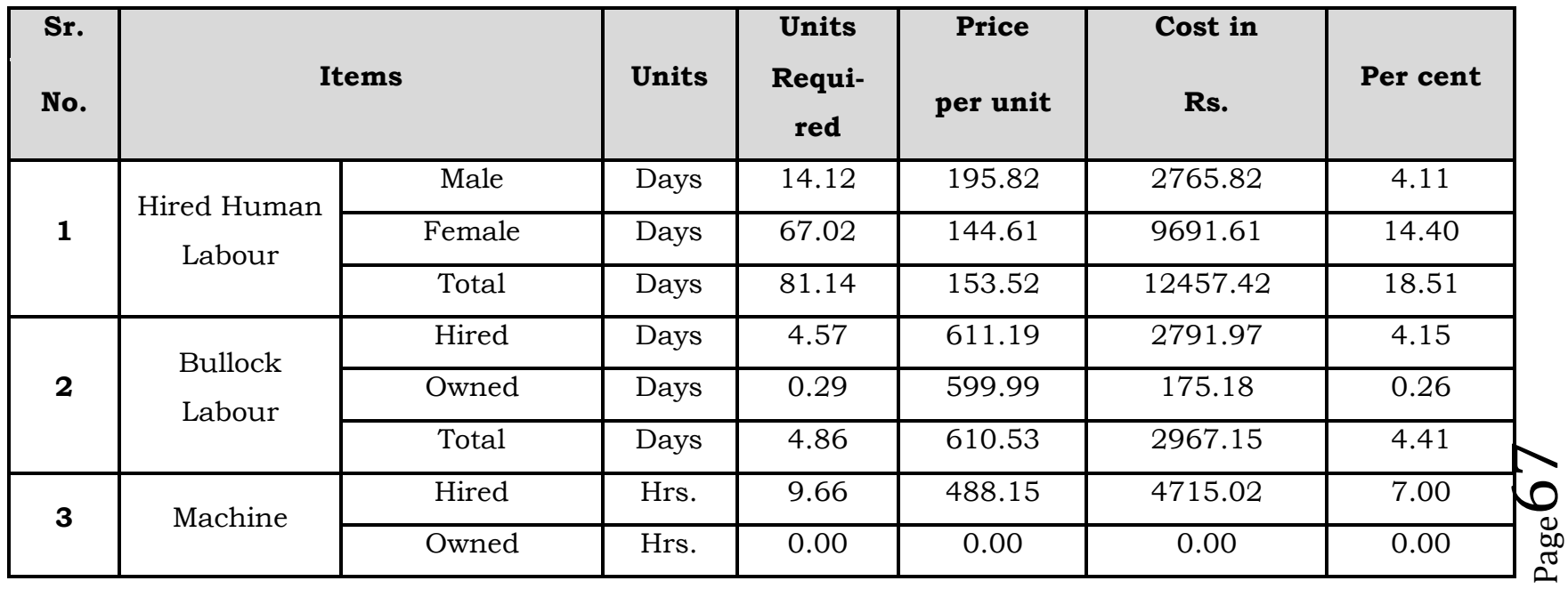




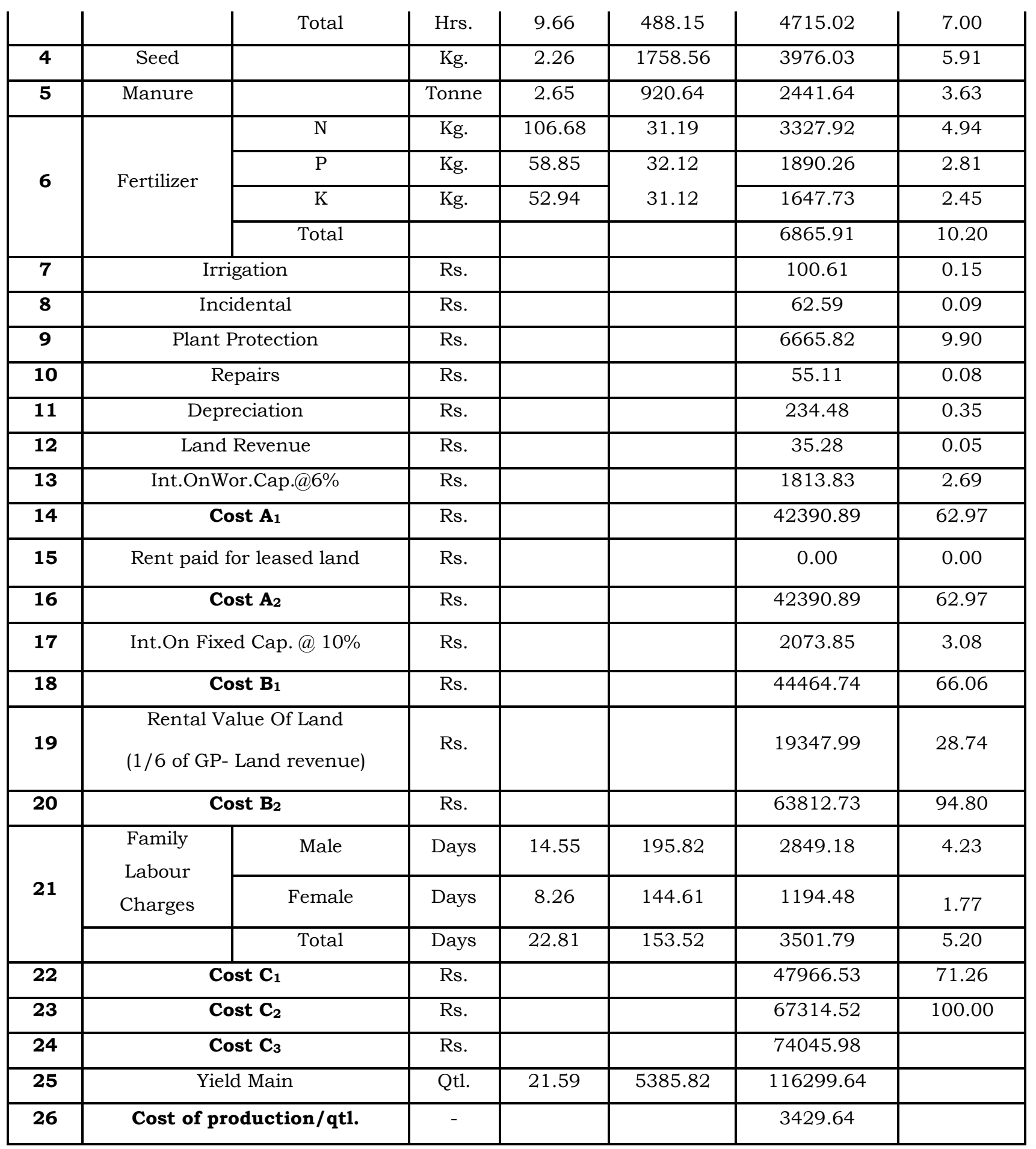


Table 7: Per hectare cost of cultivation of (Medium)

\begin{tabular}{|c|c|c|c|c|c|c|c|}
\hline $\begin{array}{l}\text { Sr. } \\
\text { No. }\end{array}$ & \multicolumn{2}{|c|}{ Items } & Units & $\begin{array}{l}\text { Units } \\
\text { Requi- } \\
\text { red }\end{array}$ & $\begin{array}{c}\text { Price } \\
\text { per unit }\end{array}$ & $\begin{array}{l}\text { Cost in } \\
\text { Rs. }\end{array}$ & Per cent \\
\hline \multirow{3}{*}{1} & \multirow{3}{*}{$\begin{array}{l}\text { Hired } \\
\text { Human } \\
\text { Labour }\end{array}$} & Male & Days & 11.60 & 207.59 & 2408.31 & 3.85 \\
\hline & & Female & Days & 67.76 & 146.27 & 9911.61 & 15.85 \\
\hline & & Total & Days & 79.36 & 149.41 & 11857.82 & 18.96 \\
\hline \multirow{3}{*}{2} & \multirow{3}{*}{$\begin{array}{l}\text { Bullock } \\
\text { Labour }\end{array}$} & Hired & Days & 1.04 & 607.65 & 631.42 & 1.01 \\
\hline & & Owned & Days & 2.05 & 600.60 & 1229.83 & 1.97 \\
\hline & & Total & Days & 3.09 & 602.97 & 1861.25 & 2.98 \\
\hline \multirow{3}{*}{3} & \multirow{3}{*}{ Machine } & Hired & Hrs. & 8.67 & 496.12 & 4300.12 & 6.87 \\
\hline & & Owned & Hrs. & 0.10 & 575.00 & 56.23 & 0.09 \\
\hline & & Total & Hrs. & 8.77 & 497.00 & 4356.36 & 6.96 \\
\hline 4 & Seed & & $\mathrm{Kg}$. & 2.29 & 1767.49 & 4054.65 & 6.48 \\
\hline 5 & Manure & & Tonne & 1.71 & 852.90 & 1459.31 & 2.33 \\
\hline \multirow{4}{*}{6} & \multirow{4}{*}{ Fertilizer } & $\mathrm{N}$ & Kg. & 99.93 & 31.60 & 3158.06 & 5.05 \\
\hline & & $\mathrm{P}$ & Kg. & 54.35 & 32.64 & 1773.71 & 2.84 \\
\hline & & $\mathrm{K}$ & Kg. & 55.21 & 30.42 & 1679.56 & 2.69 \\
\hline & & Total & & & & 6611.33 & 10.57 \\
\hline 7 & \multicolumn{2}{|c|}{ Irrigation } & Rs. & & & 124.94 & 0.20 \\
\hline 8 & \multicolumn{2}{|c|}{ Incidental } & Rs. & & & 32.69 & 0.05 \\
\hline 9 & \multicolumn{2}{|c|}{ Plant Protection } & Rs. & & & 5002.08 & 8.00 \\
\hline 10 & \multicolumn{2}{|c|}{ Repairs } & Rs. & & & 74.51 & 0.12 \\
\hline 11 & \multicolumn{2}{|c|}{ Depreciation } & Rs. & & & 257.16 & 0.41 \\
\hline 12 & \multicolumn{2}{|c|}{ Land Revenue } & Rs. & & & 35.28 & 0.06 \\
\hline 13 & \multicolumn{2}{|c|}{ Int. On Wor. Cap. @6\% } & Rs. & & & 1594.57 & 2.55 \\
\hline 14 & \multicolumn{2}{|c|}{ Cost $\mathbf{A}_{1}$} & Rs. & & & 37321.94 & 59.67 \\
\hline 15 & \multicolumn{2}{|c|}{ Rent paid for leased land } & Rs. & & & 0.00 & 0.00 \\
\hline 16 & \multicolumn{2}{|c|}{ Cost $\mathbf{A}_{2}$} & Rs. & & & 37321.94 & 59.67 \\
\hline 17 & \multicolumn{2}{|c|}{ Int.on Fixed Cap.@10\% } & Rs. & & & 2233.95 & 3.57 \\
\hline 18 & \multicolumn{2}{|c|}{ Cost $B_{1}$} & Rs. & & & 39555.89 & 63.24 \\
\hline 19 & \multicolumn{2}{|c|}{$\begin{array}{c}\text { Rental Value Of Land } \\
\text { (1/6 of GP- Land revenue) }\end{array}$} & Rs. & & & 20949.29 & $\begin{array}{l}33.49 \\
0.00\end{array}$ \\
\hline 20 & \multicolumn{2}{|c|}{ Cost $\mathbf{B}_{2}$} & Rs. & & & 60505.17 & 96.73 \\
\hline \multirow{3}{*}{21} & $\begin{array}{l}\text { Family } \\
\text { Labour }\end{array}$ & Male & Days & 9.32 & 207.59 & 1933.78 & 3.09 \\
\hline & Charges & Female & Days & 4.36 & 146.27 & 638.32 & 1.02 \\
\hline & & Total & Days & 13.68 & 149.41 & 2043.93 & 3.27 \\
\hline
\end{tabular}




\begin{tabular}{|c|c|c|c|c|c|c|}
\cline { 2 - 6 } 22 & Cost $\mathbf{C}_{\mathbf{1}}$ & Rs. & & & 41599.81 & 66.51 \\
\hline 23 & Cost $\mathbf{C}_{\mathbf{2}}$ & Rs. & & & 62549.10 & 100.00 \\
\hline 24 & Cost $\mathbf{C}_{\mathbf{3}}$ & Rs. & & & 68804.01 & \\
\hline 25 & Yield Main & Qtl. & 23.06 & 5457.72 & 125833.25 & \\
\hline 26 & Cost of production/qt1. & - & & & 2984.21 & \\
\hline
\end{tabular}

Table 8: Per hectare cost of cultivation (Large)

\begin{tabular}{|c|c|c|c|c|c|c|c|}
\hline $\begin{array}{l}\text { Sr. } \\
\text { No. }\end{array}$ & \multicolumn{2}{|c|}{ Items } & Units & Units & $\begin{array}{c}\text { Price } \\
\text { per unit }\end{array}$ & $\begin{array}{c}\text { Cost in } \\
\text { Rs. }\end{array}$ & Per cent \\
\hline \multirow{3}{*}{1} & \multirow{3}{*}{$\begin{array}{l}\text { Hired } \\
\text { Human } \\
\text { Labour }\end{array}$} & Male & Days & 11.71 & 212.10 & 2483.71 & 3.71 \\
\hline & & Female & Days & 76.66 & 146.53 & 11233.55 & 16.77 \\
\hline & & Total & Days & 88.37 & 155.22 & 13717.26 & 20.48 \\
\hline \multirow{3}{*}{2} & \multirow{3}{*}{$\begin{array}{l}\text { Bullock } \\
\text { Labour }\end{array}$} & Hired & Days & 0.37 & 606.67 & 222.31 & 0.33 \\
\hline & & Owned & Days & 3.69 & 608.83 & 2245.93 & 3.35 \\
\hline & & Total & Days & 4.06 & 608.63 & 2468.24 & 3.69 \\
\hline \multirow{3}{*}{3} & \multirow{3}{*}{ Machine } & Hired & Hrs. & 8.37 & 576.17 & 4823.29 & 7.20 \\
\hline & & Owned & Hrs. & 1.42 & 408.06 & 578.18 & 0.86 \\
\hline & & Total & Hrs. & 9.79 & 551.85 & 5401.47 & 8.07 \\
\hline 4 & Seed & & Kg. & 2.29 & 1719.41 & 3931.60 & 5.87 \\
\hline 5 & Manure & & Tonne & 3.09 & 907.40 & 2807.50 & 4.19 \\
\hline \multirow{4}{*}{6} & \multirow{4}{*}{ Fertilizer } & $\mathrm{N}$ & Kg. & 99.84 & 34.11 & 3404.98 & 5.08 \\
\hline & & $\mathrm{P}$ & Kg. & 55.93 & 30.18 & 1688.24 & 2.52 \\
\hline & & $\mathrm{K}$ & Kg. & 51.22 & 31.95 & 1636.45 & 2.44 \\
\hline & & Total & & & & 6729.67 & 10.05 \\
\hline 7 & \multicolumn{2}{|c|}{ Irrigation } & Rs. & & & 120.52 & 0.18 \\
\hline 8 & \multicolumn{2}{|c|}{ Incidental } & Rs. & & & 27.93 & 0.04 \\
\hline 9 & \multicolumn{2}{|c|}{ Plant Protection } & Rs. & & & 5526.06 & 8.25 \\
\hline 10 & \multicolumn{2}{|c|}{ Repairs } & Rs. & & & 34.45 & 0.05 \\
\hline 11 & \multicolumn{2}{|c|}{ Depreciation } & Rs. & & & 156.93 & 0.23 \\
\hline 12 & \multicolumn{2}{|c|}{ Land Revenue } & Rs. & & & 35.28 & 0.05 \\
\hline 13 & \multicolumn{2}{|c|}{ Int. on Wor. Cap.@6\% } & Rs. & & & 1834.411 & 2.74 \\
\hline 14 & \multicolumn{2}{|c|}{ Cost $\mathbf{A}_{1}$} & Rs. & & & 42791.31 & 63.90 \\
\hline 15 & \multicolumn{2}{|c|}{ Rent paid For leased land } & Rs. & & & 0.00 & 0.00 \\
\hline 16 & \multicolumn{2}{|c|}{ Cost $\mathbf{A}_{2}$} & Rs. & & & 42791.31 & 63.90 \\
\hline 17 & \multicolumn{2}{|c|}{ Int.On Fixed Cap.@10\% } & Rs. & & & 2018.37 & 3.01 \\
\hline 18 & \multicolumn{2}{|c|}{ Cost $\mathbf{B}_{1}$} & Rs. & & & 44809.68 & 66.91 \\
\hline
\end{tabular}




\begin{tabular}{|c|c|c|c|c|c|c|c|}
\hline 19 & \multicolumn{2}{|c|}{$\begin{array}{c}\text { Rental Value Of Land } \\
\text { (1/6 of GP- Land revenue) }\end{array}$} & Rs. & & & 21018.95 & 31.39 \\
\hline 20 & \multicolumn{2}{|c|}{ Cost $\mathbf{B}_{2}$} & Rs. & & & 65828.63 & 98.29 \\
\hline \multirow{3}{*}{21} & \multirow{2}{*}{$\begin{array}{l}\text { Family } \\
\text { Labour } \\
\text { Charges }\end{array}$} & Male & Days & 6.37 & 212.10 & 1350.65 & 2.02 \\
\hline & & Female & Days & 0.99 & 146.53 & 145.06 & 0.22 \\
\hline & & Total & Days & 7.36 & 155.22 & 1142.65 & 1.71 \\
\hline 22 & \multicolumn{2}{|c|}{ Cost $\mathrm{C}_{1}$} & Rs. & & & 45952.33 & 68.61 \\
\hline 23 & \multicolumn{2}{|c|}{ Cost $\mathrm{C}_{2}$} & Rs. & & & 66971.28 & 100.00 \\
\hline 24 & \multicolumn{2}{|c|}{ Cost $\mathrm{C}_{3}$} & Rs. & & & 73668.41 & \\
\hline 25 & \multicolumn{2}{|c|}{ Yield Main } & Qtl. & 24.04 & 5249.65 & 126196.25 & \\
\hline 26 & \multicolumn{2}{|c|}{ Cost of production/qtl } & - & & & 3064.54 & \\
\hline
\end{tabular}

Table 9: Per hectare cost of cultivation (Overall)

\begin{tabular}{|c|c|c|c|c|c|c|c|}
\hline $\begin{array}{l}\text { Sr. } \\
\text { No. }\end{array}$ & \multicolumn{2}{|c|}{ Items } & Units & $\begin{array}{l}\text { Units } \\
\text { requir }\end{array}$ & $\begin{array}{c}\text { Price } \\
\text { Per unit }\end{array}$ & $\begin{array}{c}\text { Cost in } \\
\text { Rs. }\end{array}$ & Per cent \\
\hline \multirow{3}{*}{1} & \multirow{3}{*}{$\begin{array}{l}\text { Hired Human } \\
\text { Labour }\end{array}$} & Male & Days & 12.61 & 203.91 & 2570.63 & 3.91 \\
\hline & & Female & Days & 70.23 & 145.77 & 10236.90 & 15.57 \\
\hline & & Total & Days & 82.83 & 152.58 & 12639.09 & 19.23 \\
\hline \multirow{3}{*}{2} & \multirow{3}{*}{ Bullock Labour } & Hired & Days & 2.15 & 610.35 & 1313.73 & 2.00 \\
\hline & & Owned & Days & 1.86 & 605.04 & 1127.01 & 1.71 \\
\hline & & Total & Days & 4.02 & 607.88 & 2440.73 & 3.71 \\
\hline \multirow{3}{*}{3} & \multirow{3}{*}{ Machine } & Hired & Hrs. & 8.99 & 513.37 & 4614.42 & 7.02 \\
\hline & & Owned & Hrs. & 0.42 & 422.15 & 178.69 & 0.27 \\
\hline & & Total & Hrs. & 9.41 & 509.27 & 4793.12 & 7.29 \\
\hline 4 & Seed & & Kg. & 2.28 & 1751.20 & 3992.74 & 6.07 \\
\hline 5 & Manure & & Tonne & 1.22 & 1797.50 & 2194.74 & 3.34 \\
\hline \multirow{4}{*}{6} & \multirow{4}{*}{ Fertilizer } & $\mathrm{N}$ & Kg. & 102.83 & 31.58 & 3247.19 & 4.94 \\
\hline & & $\mathrm{P}$ & Kg. & 57.45 & 31.81 & 1827.66 & 2.78 \\
\hline & & $\mathrm{K}$ & Kg. & 53.53 & 31.08 & 1663.59 & 2.53 \\
\hline & & Total & & & & 6738.44 & 10.25 \\
\hline 7 & \multicolumn{2}{|c|}{ Irrigation } & Rs. & & & 115.37 & 0.18 \\
\hline 8 & \multicolumn{2}{|c|}{ Incidental } & Rs. & & & 42.49 & 0.06 \\
\hline 9 & \multicolumn{2}{|c|}{ Plant Protection } & Rs. & & & 5777.18 & 8.79 \\
\hline 10 & \multicolumn{2}{|c|}{ Repairs } & Rs. & & & 56.77 & 0.09 \\
\hline 11 & \multicolumn{2}{|c|}{ Depreciation } & Rs. & & & 222.57 & 0.34 \\
\hline 12 & \multicolumn{2}{|c|}{ Land Revenue } & Rs. & & & 35.28 & 0.05 \\
\hline
\end{tabular}




\begin{tabular}{|c|c|c|c|c|c|c|c|}
\hline 13 & \multicolumn{2}{|c|}{ Int. On Wor. Cap. @6\% } & Rs. & & & 1745.58 & 2.66 \\
\hline 14 & \multicolumn{2}{|c|}{ Cost $\mathbf{A}_{1}$} & Rs. & & & 40794.10 & 62.06 \\
\hline 15 & \multicolumn{2}{|c|}{ Rent paid For leased land } & Rs. & & & 0.00 & 0.00 \\
\hline 16 & \multicolumn{2}{|c|}{ Cost $\mathbf{A}_{2}$} & Rs. & & & 40794.10 & 62.06 \\
\hline 17 & \multicolumn{2}{|c|}{ Int.On Fixed Cap.@10\% } & Rs. & & & 2125.64 & 3.23 \\
\hline 18 & \multicolumn{2}{|c|}{ Cost $B_{1}$} & Rs. & & & 42919.74 & 65.29 \\
\hline 19 & \multicolumn{2}{|c|}{$\begin{array}{l}\text { Rental Value Of Land } \\
\text { (1/6 of GP- Land revenue) }\end{array}$} & Rs. & & & 20475.13 & 31.15 \\
\hline 20 & \multicolumn{2}{|c|}{ Cost $\mathbf{B}_{2}$} & Rs. & & & 63394.88 & 96.44 \\
\hline \multirow{3}{*}{21} & Family Labour & Male & Days & 10.47 & 203.91 & 2134.33 & 3.25 \\
\hline & Charges & Female & Days & 4.89 & 145.77 & 712.52 & 1.08 \\
\hline & & Total & Days & 15.36 & 152.58 & 2343.02 & 3.56 \\
\hline 22 & \multicolumn{2}{|c|}{ Cost $\mathbf{C}_{1}$} & Rs. & & & 45262.76 & 68.85 \\
\hline 23 & \multicolumn{2}{|c|}{ Cost $\mathbf{C}_{2}$} & Rs. & & & 65737.89 & 100.00 \\
\hline 24 & \multicolumn{2}{|c|}{ Cost $\mathrm{C}_{3}$} & Rs. & & & 72311.68 & \\
\hline 25 & \multicolumn{2}{|c|}{ Yield Main } & Qtl. & 22.89 & 5373.10 & 123001.07 & \\
\hline 26 & \multicolumn{2}{|c|}{ Cost of production/qtl. } & - & & & 3158.82 & \\
\hline
\end{tabular}

